DOI

\title{
ЦИТОКІНОВИЙ СТАТУС У ХВОРИХ ІЗ ЗАПАЛЬНО-ДЕСТРУКТИВНИМИ УРАЖЕННЯМИ ПАРОДОНТА НА ТЛІ ГАСТРОЕЗОФАГЕАЛЬНОЇ РЕФЛЮКСНОӦ ХВОРОБИ ЗАЛЕЖНО ВІД ПЕРЕБІГУ ЗАХВОРЮВАННЯ
}

\author{
○В. Я. Лобанець ${ }^{1}$ В. Р. Перейма², І. М. Смільська \\ ДВНЗ «Тернопільський державний медичний університет імені І. Я. Горбачевського МОз України»' \\ Тернопільська міська комунальна лікарня № $2^{2}$ \\ Тернопільське районне територіальне медичне об'єднанняз
}

PEЗЮМЕ. У статті досліджено та проаналізовано зміни рівнів про- і протизапальних цитокінів, а саме: IL-1及, IL-12 та IL-4, у хворих із запально-деструктивними захворюваннями пародонта на тлі гастроезофагеальної рефлюксної хвороби залежно від перебігу захворювання. Встановлено, що дисбаланс цитокінової відповіді місцевого і загального характеру більш виражений у пацієнтів з пародонтитом на тлі ерозивної форми гастроезофагеальної рефлюксної хвороби.

КЛЮчОВІ СЛОВА: пародонт, гастроезофагеальна рефлюксна хвороба, цитокіни.

Вступ. Гастроезофагеальна рефлюксна хвороба (ГЕРХ) та патологія тканин пародонта $\epsilon$ поширеними хронічними захворюваннями у світі. Ця проблема $\epsilon$ актуальною через швидке зростання чисельності ГЕРХ з щорічним приростом близько 5 \% [3].

За даними літератури, зміна мінерального складу й в'язкості слини із розвитком ацидифікації $(\mathrm{pH}<7,0)$ та подальшим індукуванням цитокінових реакцій запускає каскад стоматологічних ушкоджень при ГEPX $[1,5] .3$ публікацій останніх років стає очевидним, що прозапальні цитокіни, які продукуються активованими макрофагами та моноцитами під впливом ендотоксинів пародонтогенних бактерій, не тільки запускають, але й підтримують запальний процес у пародонті [8]. Персистуючий викид медіаторів запалення першої ланки, як інтерлейкін-1ß (IL-1ß), обумовлює активацію матриксних металопротеїназ, зниження продукції колаген-синтетази та протеогліканів, що призводить до деструкції кісткової тканини [10].

Цитокіни в організмі людини відіграють важливу роль як регулятори місцевої та системної дії, медіатори міжклітинних взаємодій, включаючи диференціацію, функціональну активність та апоптоз клітин та узгодженість роботи імунної, нейроендокринної систем у нормальних умовах та у відповідь на дію патогенного чинника [9]. Дослідження останніх десятиліть довели, що цитокіни $\epsilon$ тригерами запального процесу у тканинах пародонта та предикторами прогресування патологічних змін у них.

Відомо, що IL-1 $\beta$ має прозапальні властивості, впливаючи безпосередньо на тропні клітини. У фібробластах й остеокластах при наявності запального процесу лімфокін стимулює метаболізм арахідонової кислоти та, як наслідок, синтез про- стацикліну та простагландину E2, посилює секрецію запальних протеаз (еластази, колагенази), тим самим зумовлюючи розсмоктування не тільки кісткової, але й хрящової тканини [4]. У доступній літературі висвітлено наявний сильний прямий зв'язок між рівнем IL-1 $\beta$ та резорбцією кістки. Крім того, цей цитокін індукує продукцію інших прозапальних медіаторів запалення й простагландинів, посилює проліферацію Т-, В-лімфоцитів, адгезію моноцитів й нейтрофілів, посилює хемотаксис і фагоцитоз, тим самим забезпечуючи реалізацію механізмів неспецифічного захисту та специфічної імунної відповіді $[1,11]$.

Інший прозапальний лімфокін - інтерлейкін12 (IL-12) безпосередньо задіяний у формуванні антиген-специфічного (набутого) імунітету шляхом стимуляції генерування Т-лімфоцитів (CD4+) у Т-хелпери першого класу (Th-1). Доведено, що внаслідок дії альтеруючого чинника на організм, тип диференціації Т-лімфоцитів визначається балансом між IL-12 й IL-4, які направляють генерування у Th-1- чи Т-хелпери другого класу (Th-2) відповідно $[2,8]$. Відомо що, лімфокін надмірно виробляється у організмі вже на ранніх стадіях гострих чи загострення хронічних захворювань, що, у свою чергу, слугує маркером запального процесу. У науковій літературі зустрічаються публікації, в яких діагностичним критерієм ступеня тяжкості й активності патологічного процесу у пародонті визначено саме IL-12 [11].

Встановлено, що IL-4 проявляє потужний протизапальний ефект та відіграє ключову роль у виникненні запальної реакції. Також зменшує запальні функції моноцитів й макрофагів, регулює диференціацію CD4+ у Т-хелпери другого класу (Th-2). Останні ж забезпечують гуморальну відповідь організму $[8,4]$. 
Огляди літератури, оригінальні дослідження, погляд на проблему

Мета дослідження - встановити зв'язок між ступенем ураження тканин пародонта та рівнем про- і протизапальних цитокінів, а саме: IL-1 $\beta$, IL-12 та IL-4, у хворих на ГEPX залежно від ступеня ураження слизової оболонки.

Матеріал і методи дослідження. Для дослідження шляхом випадкового підбору відібрано 85 хворих на ГЕРХ, зіставних за статтю й віком. Групу порівняння склали 20 практично здорових осіб.

Аналіз нозологічних форм тканин пародонта на тлі ГЕРХ обумовив формування наступних діагностичних груп. Групу неерозивну ГЕРX I сформували пацієнти з інтактним пародонтом у кількості 16 осіб проти 46 пацієнтів з різними ступенями проявів гінгівіту (неерозивну ГЕРХ II). Пацієнтів з ерозивною формою ГЕРХ поділили на групи за ступенем ураження слизових оболонок (ерозивну ГЕРХІ, 11 осіб) та тканин пародонта (ерозивну ГЕРX II, 12 осіб).

Дослідження вмісту про- та протизапальних цитокінів - IL-1 $\beta$, IL-4, IL-12 проводили за допомогою імуноферментного аналізу з використанням наборів реактивів фірми «Вектор-Бест» (РФ, Новосибірськ) на апараті «Stattfax 303 plus». Meтод базується на твердофазному «сендвічі» із застосуванням моно- і поліклональних антитіл до IL-1 $\beta$, IL-4, IL-12. Матеріалом дослідження була сироватка крові й вміст ясенної і пародонтальної кишень.

Статистичну обробку результатів виконували за допомогою пакета програм Microsoft Excel, Statistica 8.0. Для виявлення статистичної значущої різниці показників між підгрупами застосовували непараметричний U-критерій Манна-Уітні. Критичний рівень значущості при перевірці статистичних гіпотез у дослідах приймався рівним 0,05 [7].

Результати й обговорення. Аналіз рівня досліджуваних цитокінів продемонстрував зро- стання вмісту прозапального цитокіну IL-1 $1 \beta$ у групі 3 неерозивною ГЕРХ у 1,1 раза, серед пацієнтів 3 ерозивною ГЕРХ - у 1,7 раза, порівняно з групою контролю $(p<0,05)$ зі значущою міжгруповою різницею $(p<0,05)$. Підвищення концентрації прозапального IL-12, порівняно з групою контролю, у 1,6 раза, визначено у хворих з неерозивною формою ГЕРХ $(p<0,05)$ та 1,7 раза - з ерозивною $(p<0,05)$. Поряд 3 цим зареєстровано значуще підвищення протизапального IL-4 у 3,2 раза серед пацієнтів з неерозивним ураженням стравоходу та у 3,4 раза - з ерозивним стосовно групи контролю $(p<0,05)$, з міжгруповою різницею показника $(p<0,05)$.

Відображенням запального процесу у пацієнтів з гінгівітом та пародонтитом на тлі ерозивної форми ГЕРХ було зростання у 1,7 раза $(p<0,05)$ кістковорезорбтивного IL-1 $\beta$ (табл. 1). Визначено також підвищення концентрації у сироватці крові прозапального IL-12, значення якого превалювало у 1,7 раза $(p<0,05)$ у хворих з гінгівітом та у 1,6 раза $(p<0,05)$ з пародонтитом на тлі ерозивного рефлюкс-езофагіту щодо групи контролю, з наявною міжгруповою різницею $(p<0,05)$. У свою чергу, рівень протизапального IL-4 перевищував контрольний у 3,4 раза $(p<0,05)$ у обох групах 3 ерозивною формою ГЕРХ.

У групах хворих на фоні неерозивного ураження стравоходу з інтактним пародонтом та гінгівітом відмічено зростання у 1,1 раза показника IL-1 $\beta$ у сироватці крові $(p<0,05)$ порівняно з контрольним (табл. 2). Рівень прозапального IL-12 підвищився у 1,6 раза $(p<0,05)$ у пацієнтів з інтактним пародонтом. У свою чергу, концентрація протизапального IL-4 перевищувала контрольний показник у 3,2 раза $(p<0,05)$ у хворих з інтактним пародонтом та у 3,3 раза $(p<0,05)$ у пацієнтів з гінгівітом та неерозивним ураженням стравоходу.

Таблиця 1. Концентрація цитокінів у сироватці крові хворих з ерозивною формою ГЕРХ (M士m)

\begin{tabular}{|c|c|c|c|}
\hline \multirow{2}{*}{ Показник } & \multirow{2}{*}{$\begin{array}{c}\text { Група } \\
\text { контролю, n=20 }\end{array}$} & \multicolumn{2}{|c|}{ Хворі з ерозивною ГЕРХ, $n=23$} \\
\hline & & ерозивна ГЕРХ I, n=11 & ерозивна ГЕРХ II, $\mathrm{n}=12$ \\
\hline $\mathrm{IL}-1 \beta$, пг/мл & $1,26 \pm 0,10$ & $1,71 \pm 0,01 *$ & $1,73 \pm 0,02 *$ \\
\hline IL-4, пг/мл & $1,41 \pm 0,01$ & $4,89 \pm 0,01^{*}$ & $4,83 \pm 0,02 *$ \\
\hline IL-12, пг/мл & $8,93 \pm 0,02$ & $14,86 \pm 0,03 *$ & $14,54 \pm 0,04 * / \Delta$ \\
\hline
\end{tabular}

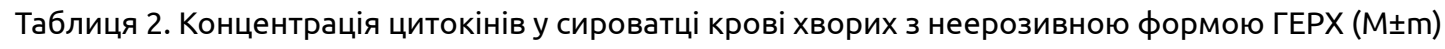

\begin{tabular}{|c|c|c|c|}
\hline \multirow{2}{*}{ Показник } & \multirow{2}{*}{$\begin{array}{c}\text { Група } \\
\text { контролю, } \mathrm{n}=20\end{array}$} & \multicolumn{2}{|c|}{ Хворі з неерозивною ГЕРХ, n=62 } \\
\hline & & неерозивна ГЕРХ I, n=16 & неерозивна ГЕРХ II, $\mathrm{n}=46$ \\
\hline $\mathrm{IL}-1 \beta$, пг/мл & $1,26 \pm 0,10$ & $1,37 \pm 0,01 *$ & $1,31 \pm 0,02^{*}$ \\
\hline IL-4, пг/мл & $1,41 \pm 0,01$ & $4,52 \pm 0,03 *$ & $4,58 \pm 0,01^{*}$ \\
\hline IL-12, пг/мл & $8,93 \pm 0,02$ & $14,40 \pm 0,02 *$ & $14,28 \pm 0,03 * / \Delta$ \\
\hline
\end{tabular}


Огляди літератури, оригінальні дослідження, погляд на проблему

Аналіз коливання рівня цитокінів у сироватці крові залежно від змін в тканинах пародонта продемонстрував максимальне зростання вмісту IL-1 $\beta$ у пацієнтів з пародонтитом на фоні ерозивного ураження стравоходу $(1,73 \pm 0,02) \pi г / м л$ із вірогідною різницею у групах хворих з інтактним пародонтом та гінгівітом при неерозивній ГЕРХ $(p<0,05)$. Рівень прозапального IL-12 був найвищим серед хворих з гінгівітом на тлі ерозивної ГЕРX - $(14,86 \pm 0,03)$ пг/мл зі значущою різницею щодо групи пацієнтів з діагностованим пародонтитом $(p<0,05)$.

Визначено також, що концентрація протизапального IL-4 була найнижчою у пацієнтів з інтактним пародонтом. Проте показник у хворих з ерозивною формою значуще різнився від аналогічного у групі з неерозивною формою ГЕРХ $(p<0,05)$.

Отже, гіперпродукція прозапальних IL-1ß, IL-12 і протизапального IL-4 медіаторів запалення у сироватці крові хворих на гастроезофагеальну рефлюксну хворобу характеризує цитокіновий дисбаланс загального характеру, вираженість якого залежала від глибини ураження слизової оболонки стравоходу.

Виявлено зростання вмісту у ротовій рідині IL-1 $\beta$ у 1,4 раза $(p<0,05)$ у хворих на ГЕPX порівняно $з$ контрольним, з вищим рівнем у групі 3 ерозивною ГЕРХ, порівняно з неерозивною формою $(p<0,05)$. Тобто більш глибокому ураженню слизової оболонки стравоходу відповідав вищий показник прозапального IL-1 $\beta$ у ротовій рідині. У свою чергу, концентрація IL-12 зросла у 1,2 раза $(p<0,05)$, порівняно з групою контролю у хворих з рефлюкс-езофагітом. Відмічено також вірогідну різницю показника між ерозивною та неерозивною формами ГEPX $(p<0,05)$.

Концентрація протизапального IL-4 ротової рідини у групі пацієнтів з неерозивним ураженням стравоходу була вищою у 2,2 раза $(p<0,05)$ порівняно $з$ контрольною, та у 2,5 раза $(p<0,05)-3$ ерозивними змінами, з вірогідною міжгруповою різницею показника $(p<0,05)$.

Аналіз рівня досліджуваних цитокінів ротової рідини у хворих з ерозивним рефлюкс-езофагітом продемонстрував зростання у 1,4 раза прозапального IL-1 $\beta$, порівняно з контрольним показником $(p<0,05)$. Проте в групі хворих з гінгівітом на фоні ерозивної ГЕРX вміст IL-1 $\beta$ виявився вірогідно вищим, ніж у групі з пародонтитом $(p<0,05)$ (табл. 3). Аналогічні зміни зареєстровані при порівнянні значення IL-12 у пацієнтів з гінгівітом при ерозивному ураженні стравоходу, $(9,30 \pm 0,02) \pi г /$ мл, проти аналогічного у хворих з пародонтитом, $(9,07 \pm 0,02)$ пг/мл $(p<0,05)$. Встановлено також значуще зростання IL-12 у профільних пацієнтів, порівняно з контрольним показником $(p<0,05)$. Концентрація протизапального IL-4 порівняно з контрольним значенням зросла у 2,4 раза $(p<0,05)$ у групі хворих з гінгівітом при ерозивній ГЕРХ та у 2,5 раза $(p<0,05)$ у групі 3 пародонтитом.

Таблиця 3. Концентрація цитокінів у ротовій рідині хворих з ерозивною формою ГЕРХ (M $\pm m)$

\begin{tabular}{|c|c|c|c|}
\hline \multirow{2}{*}{ Показник } & \multirow{2}{*}{$\begin{array}{c}\text { Група } \\
\text { контролю, n=20 }\end{array}$} & \multicolumn{2}{|c|}{ Хворі з ерозивною ГЕРХ, $n=23$} \\
\hline & & ерозивна ГЕРХ I, n=11 & ерозивна ГЕРX II, $\mathrm{n}=12$ \\
\hline $\mathrm{IL}-1 \beta$, пг/мл & $68,34 \pm 0,03$ & $96,28 \pm 0,13^{*}$ & $95,78 \pm 0,01 * / \Delta$ \\
\hline IL-4, пг/мл & $1,60 \pm 0,03$ & $3,86 \pm 0,01 *$ & $4,01 \pm 0,10^{*}$ \\
\hline $\mathrm{IL}-12$, пг/мл & $9,23 \pm 0,02$ & $9,30 \pm 0,02^{*}$ & $9,07 \pm 0,02 * / \Delta$ \\
\hline
\end{tabular}

Примітки: 1.* - різниця значуща (р<0,05) щодо групи контролю (оцінка за критерієм Манна-Уітні);

2. $\Delta$ - різниця значуща $(p<0,05)$ порівняно з ерозивною ГЕРХ I (оцінка за критерієм Манна-Уітні).

Вміст IL-1 $\beta$ у ротовій рідині хворих з неерозивною формою ГЕРХ був вищим порівняно з контрольним, зокрема: у групі з інтактним пародонтом - у 1,35 раза $(p<0,05)$, у групі пацієнтів з гінгівітом - 1,40 раза $(p<0,05)$, зі значущою міжгруповою різницею $(p<0,05)$ (табл. 4). Аналогічні зміни підвищення концентрації IL-12 встановлено у пацієнтів з неерозивним ураженням стравоходу щодо групи контролю $(p<0,05)$. Виявлено й зростання вмісту протизапального IL-4 у хворих з інтактним пародонтом й рефлюкс-езофагітом у 1,48 раза $(p<0,05)$ та у 2,40 раза $(p<0,05)$ у пацієнтів з гінгівітом, порівняно з контрольним. Цікаво, що при виникненні гінгівіту на тлі неерозивної форми ГЕРХ концентрація IL-4 у ротовій рідині зросла у 1,62 раза щодо групи з інтактним пародонтом $(p<0,05)$.
Так, найвищий показник кістковорезорбційного IL-1 $\beta$ ротової рідини - $(96,28 \pm 0,13)$ пг/мл - визначено у групі хворих з пародонтитом на тлі ГЕРХ $(p<0,05)$. Цікаво, що рівень прозапального IL-1 $\beta$ у пацієнтів з гінгівітом на тлі ерозивної форми був вірогідно вищим, ніж у групі хворих з гінгівітом при неерозивному ураженні стравоходу $(p<0,05)$.

Запускаючи реакції запально-регулятивного каскаду, IL-1 $\beta$ відіграє важливу роль у розвитку місцевого запального процесу. Гіперпродукція цього біологічно активного медіатора у ротовій рідині хворих з гінгівітом та пародонтитом розглядається як показник активності та прогресування захворювань пародонта на тлі ГЕРХ.

Інший прозапальний цитокін - IL-12 - характеризувався значущо вищими показниками у 
Огляди літератури, оригінальні дослідження, погляд на проблему

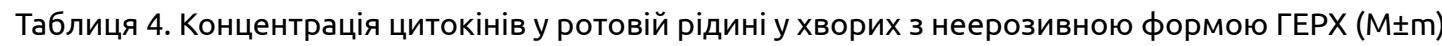

\begin{tabular}{|c|c|c|c|}
\hline \multirow{2}{*}{ Показник } & \multirow{2}{*}{$\begin{array}{c}\text { Група } \\
\text { контролю, } \mathrm{n}=20\end{array}$} & \multicolumn{2}{|c|}{ Хворі з неерозивною ГЕРХ, n=62 } \\
\hline & & неерозивна ГЕРХ I, n=16 & неерозивна ГЕРХ I, n=46 \\
\hline $\mathrm{IL}-1 \beta$, пг/мл & $68,34 \pm 0,03$ & $92,49 \pm 0,03 *$ & $95,79 \pm 0,01 * / \Delta$ \\
\hline IL-4, пг/мл & $1,60 \pm 0,03$ & $2,37 \pm 0,02^{*}$ & $3,84 \pm 0,01 * / \Delta$ \\
\hline $\mathrm{IL}-12$, пг/мл & $9,23 \pm 0,02$ & $11,28 \pm 0,01^{*}$ & $11,42 \pm 0,03 *$ \\
\hline
\end{tabular}

хворих з неерозивним ураженням стравоходу, порівняно з ерозивним на тлі ГЕРХ: у групі хворих з інтактним пародонтом його рівень сягнув $(11,28 \pm 0,01)$ пг/мл, з гінгівітом - $(11,42 \pm 0,03)$ пг/мл проти $(9,30 \pm 0,02)$ пг/мл (рHEPX I,Il<0,05) у хворих 3 гінгівітом й ерозивним рефлюкс-езофагітом та $(9,07 \pm 0,02)$ пг/мл (pHEPX I,Il<0,05) у хворих з пародонтитом. Тобто, вираженість запального процесу у ротовій порожнині за рівнем IL-12 була вищою при неерозивній формі ГЕРХ, як у пацієнтів з інтактним пародонтом, так і з гінгівітом, тоді як ерозивне ураження стравоходу перебігало на фоні зниження рівня даного біологічно активного медіатора при гінгівіті та досягнення значення практично рівня групи контролю при пародонтиті на тлі ГЕРХ. Тобто, практично відсутнє зростання рівня прозапального IL-12 дає можливість припустити про зменшення значення даного лімфокіну у патогенезі пародонтиту.

Висновки. 1. Провідною ланкою у розвитку захворювань пародонта на тлі гастроезофагеальної рефлюксної хвороби визначено дисба- ланс цитокінової відповіді місцевого і загального характеру.

2. Зміни рівня цитокінів у сироватці крові залежать від глибини ураження слизової оболонки стравоходу. Так, вміст прозапального IL-1 $\beta$ виявився найвищим при ерозивній формі гастроезофагеальної рефлюксної хвороби та пародонтиті, а прозапального IL-12 - у хворих з гінгівітом на тлі ерозивного ураження стравоходу, що свідчить про більш несприятливий перебіг захворювань.

3. Гіперпродукція IL-1ß при одночасному зниженні IL-12 за вмістом ясенної кишені у хворих з ерозивною формою гастроезофагеально рефлюксної хвороби $\epsilon$ показником розвитку деструктивно-запальних змін тканин пародонта.

Перспективи подальших досліджень. У подальшому слід вивчити зміни рівнів інших цитокінів, зокрема IL-2, IL-10, у хворих із пародонтитом на тлі гастроезофагеальної рефлюксної хвороби, з метою розрахунку діагностичних індексів прогресування уражень тканин пародонта на тлі гастроезофагеальної рефлюксної хвороби.

\section{ЛІТЕРАТУРА}

1. Бандрівський Ю. Л. Стан органів порожнини рота при деструктивно-запальних захворюваннях гастродуоденальної зони : огляд літератури / Ю. Л. Бандрівський, О. О. Бандрівська, Н. Н. Бандрівська // Клінічна стоматологія. - 2014. - №2. C. 12-16.

2. Ешану В. С. Цитокины и их биологические эффекты при некоторых болезнях печени / В. С. Ешану // Клинические перспективы гастроэнтерологии, гепатологии. 2004. - № 5. - C. 11-16.

3. Колісник С. П. Гастроезофагеальна рефлюксна хвороба: актуальні питання сучасної діагностики, лікування та профілактики : огляд / С. П. Колісник, В. М. Чорноборвий // Сучасна гастроентерологія. 2006. - № 1.- С. 93-97.

4. Кирнус Н. И. Клиническое значение оксида азота и цитокинов при хронических заболеваниях верхних отделов пищеварительного тракта у детей / Н. И. Кирнус, Г. Р. Артамонов, И. Е. Смирнов // Педиатрия. - 2008. T. 86, № 6. - С. 14-18.

5. Маев И. В. Стоматологические проявления ГЕРХ В полости рта / И. В. Маев // Клиническая медицина. 2005. - № 11. - С. 33-38.
6. Мельничук Г. М. Рівень цитокінів у сироватці крові у хворих на генералізований пародонтит / Г. М. Мельничук // Український медичний часопис. 2005. - № 3 (47). - С. 104-106.

7. Реброва О. Ю. Статистический анализ медицинских данных. Применение пакета прикладных программ STATISTICA / О. Ю. Реброва - Москва, 2003. 305 c.

8. Сукманський О. І. Цитокіни - нова система біорегуляторів / О. І. Сукманський // Вісник стоматології. 2005. - № 3. - С. 69-74.

9. Чайковская И. В. Изменение уровня цитокинов при генерализованном пародонтите / И. В. Чайковская // Український стоматологічний альманах. - 2005. - № 1. - С. 14-17.

10. Meurman J. M. Oral and dental manifestation of GERD / J. M. Meurman // Oral Surg. - 2004. - Vol. 74. P. 583-589.

11. IL-4 expression delays eosinophil- independent vasculopathy and fibrosis during allograft rejection the mouse / E. M. Roberts, S. de Hall, S. Ferguson, S. Minson // J. Clin. Immunol. - 2003. - Vol. 23. - P. 119-131. 
Огляди літератури, оригінальні дослідження, погляд на проблему

CYTOKINE STATUS IN PATIENTS WITH INFLAMMATORY AND DESTRUCTIVE LESIONS

OF PARODONTIUM ON THE BACKGROUND OF GASTROESOPHAGEAL REFLUX DISEASE

DEPENDING ON THE COURSE OF THE DISEASE

○V. Ya. Lobanets', V. R. Pereyma², I. M. Smilska ${ }^{3}$

SHEI «Ternopil State Medical University by I. Ya. Horbachevsky of MPH of Ukraine» ${ }^{1}$

Ternopil Town Municipal Hospital No. $2^{2}$

Ternopil District Territorial Medical Association ${ }^{3}$

SUMMARY. The article studied and analyzed the changes of levels of pro- and anti-inflammatory cytokines IL-1ß, IL-12 and IL-4 in patients with inflammatory and destructive diseases of parodontium on the background of gastroesophagealreflux disease depending on the course of the disease. There was determined that disbalance of cytokine response of local and general character is more expressed in patients with parodatitis on the background of erosive form of gastroesophageal reflux disease.

KEY WORDS: parodontium, gastroesophageal reflux disease, cytokines.

Отримано 17.06.2015 